\title{
DISCLOSURE OF GREEN ACCOUNTING ON FINANCIAL PERFORMANCE
}

\author{
Noviansyah Rizal, Mimin Yatminiwati \\ Departement of Accountinng, STIE Widya Gama Lumajang, Indonesia \\ Email: noviansyah.rizal@gmail.com
}

\section{A R T ICLE INFO}

Date of entry:

5 Oktober 2019

Revision Date:

21 November 2019

Date Received:

10 Desember 2019

\begin{abstract}
A B S T R A C T
This study aims to determine the effect of environmental accounting disclosures on stock performance on companies listed on the Indonesia Stock Exchange. Companies that already run their businesses, then there is a possibility that these companies have great potential to have positive and negative impacts on market needs. The sample of this research is the manufacturing sector from 2011-2015. The data analysis technique used is a simple linear regression analysis by analyzing the independent variables of environmental accounting disclosure measured using proper in influencing the dependent variable of stock performance measured using stock returns. The results of this study show that environmental accounting disclosures have a positive effect on stock performance.
\end{abstract}

Keywords: Green Accounting, Financial Performance

Cite this as: Rizal, N., Yatminiwati, M. (2020). DISCLOSURE OF GREEN ACCOUNTING ON FINANCIAL PERFORMANCE. Assets : Jurnal Ilmiah Ilmu Akuntansi, Keuangan dan Pajak, 4(1), 1-7.

\section{INTRODUCTION}

Companies that already run their businesses, then there is a possibility that these companies have great potential to have positive and negative impacts on market needs. These impacts occur as a result of several internal factors within the company. One impact is related to the company's financial performance; of course, be the main focus for investors in making decisions. Other impacts can occur from external parties, for example when our forest life is polluted as land for exploitation areas, and companies can contaminate protected debt damage, and also damage to biodiversity in the forests, not only forests that are damaged in life in water is often polluted by companies, then the ecosystem in aquatic life will be polluted due to the actions of the company, It was concluded that the company must pay attention to the negative impacts that are issued; the environmental impact is a burden on the environment from the company's business operations or other potential human activities. This is where accounting science plays a role, namely, environmental accounting. Researchers concluded from part of the definitions revealed by scientists, the science of environmental accounting is the cost of environmental costs or environmental posts that are linked to companies or government institutions. These costs can be obtained from the financial and non-financial side caused by environmental influences. 
The word Disclosure broadly means something that must be elicited and informed so that no hiding occurs. Disclosure is divided into two characters, namely mandatory Disclosure and voluntary Disclosure. Disclosure of environmental accounting is still voluntary because it is still not specifically regulated in accounting standards. According to Nursasi (2017: 25), it is explained in SFAS No. 1 of 2009, paragraph nine (9) which states that companies can also provide additional reports such as reports on the environment and value-added statements, especially for industries where environmental factors play an important role and for industries that consider employees as report user groups who play an important role. Companies can submit environmental disclosure information using various media such as annual reports and financial reports. The goal is to attract investors to invest in the company.

When investors buy shares and their shares increase, the increase in shares can get profits from the purchase can be seen from changes in stock returns recorded in the financial statements. Disclosure of corporate environmental accounting can be assessed with proper ranking, which is one of the Ministry of Environment and Forestry programs. This PROP is a rating program for evaluating company performance in environmental management. According to Ikhsan (2008: 15) said that environmental accounting is a cost that directly impacts the company as a whole (in this case, referred to as "personal costs"). Second, environmental accounting also includes the costs of individuals, communities, and the environment of a company that cannot be accounted for.

Ikhsan (2009: 15) in Stick et al. (1997) "makes a clear distinction between environmental accounting and the classic concept of basic sources of accounting together with the macroeconomic perspective. Environmental accounting is defined as a subject about how environmental issues affect the traditional accounting sub-discipline ". Many experts define the theory of environmental accounting. The researcher concludes that environmental accounting is costs incurred by the company or government, and the costs are obtained by the company or government in carrying out environmental conservation, then the costs are grouped together into environmental posts. Disclosure has the meaning of not covering up or not hiding. When linked with data, Disclosure means providing useful data to those who need it. So the data must be useful because the purpose of the Disclosure will not be achieved. According to Ikhsan (2008: 130), "disclosure (disclosure) is divided into two characters, namely mandatory (voluntary) and voluntary (Voluntary). Many opinions say that the company will disclose all information needed in order to function in the capital market. " The first voluntary Disclosure that researchers knew was CSR.

According to Taufiq (2017: 43), "CSR can be interpreted as an industry commitment to account for the impact of operations in the socio-economic and environmental dimensions and maintain that these impacts contribute to the benefits of society and the environment." Many scholars explain the definition of CSR as time goes by. This CSR is mandatory Disclosure because there are one reason supporters who argue that if the information is not disclosed, it will cause the information is not relevant for investors. The purpose of the Disclosure of environmental accounting relating to environmental conservation activities undertaken by companies and governments.

Relevant Disclosure is the Disclosure of information disclosed in the financial statements that must be truly understood and that understanding must also be accompanied by adequate evidence of the information to be conveyed. According Ikhsan (2008: 35) said there are three concepts of Disclosure that are usually proposed, the first is adequate Disclosure, the second Disclosure must be fair (fair), and the third must be complete (full). Of the three concepts, on average, the most widely used in expressing is adequate Disclosure. According to Ikhsan (2008: 136) also believes that reasonable disclosures are disclosures that imply an ethical goal or provide equal treatment to all prospective readers. 
According to Fahmi (2008: 140), Disclosure in environmental accounting is a type of voluntary Disclosure. Disclosure of environmental accounting in this discussion is the Disclosure of information on environmental accounting data from the perspective of the internal function of environmental accounting itself, in the form of an environmental accounting report. The report must be based on the actual situation in a company or other organization. The actual data disclosed is determined by the company itself or other organizations. The dimensions in the Disclosure of environmental accounting data in terms of covering: 1) The process and results of environmental conservation activities. Regarding the collection of results from environmental accounting companies or other organizations will prepare a summary and the main results of environmental conservation activities, an explanation of the collection of results from environmental accounting (including an evaluation of the size and size of the figures and reasons for increasing or decreasing in comparison with the previous period), and an activated policy regarding the future of environmental conservation activities. 2) Items that form the basis of environmental accounting. Within the status, there are two influential elements to form the basis of environmental accounting, namely the target period and the scope of the collection. Status is when the target period is not an annual financial statement, and reasons must be recorded as well if related to the scope of coverage of the company, the business group has a target period for environmental accounting that is different from other companies or organizations. Whereas the scope of the collection, when determining the scope of consolidation, notes the attitude towards the importance of environmental and business group concerts that explain the actual criteria. As in the case of business, all amounts related to the company, which are related, are primary.

Index and calculation standards for environmental conservation costs. 1) Collection of depreciation costs. These are certain costs that cover depreciation costs, make a note of the effect, and if the depreciation period used is different from the use of financial concerns. 2) Standards for completeness of bookkeeping costs. In the case of standard accounting differs according to the type of environmental conservation costs, detailed records of the main methods are used for each: the main details of the environmental conservation costs collected differ from the methods of collecting and thinking about the costs of environmental conservation costs, the main details of the costs of environmental conservation costs against ( allocation, collection method, and standard allocation) because allocation is based on a simple method.

Bookkeeping standards when categories are collected relate to environmental conservation activities, among others. The main philosophy and description of the categories collected relate to environmental conservation activities if the totals for categories relate to business activities, and the amounts for areas of environmental conservation activities are different and are explained in detail. 1) Details of environmental conservation activities and standard calculations. 2) The details of the relationship between economic benefits and environmental conservation activities and standard calculations. (a) The scope of the calculation of the actual benefits, formulations, and reasons for reversing them. (b) The period in which investment profits are used in calculating the relationship of economic benefits to environmental conservation activities is the incarnation and the background to their selection. (c) In particular, if the results of the calculation of the estimated profits are disclosed, make a note that can be estimated in detail, the scope of the calculation, the calculation formulation, and the reasons. (d) In particular, if an evaluation of the economic value of environmental conservation benefits is disclosed, make a detailed record of the reasons that this value does not relate directly to the profits of the company or other organization, the scope of the calculation, the basis of the calculation method for changing each profit. The main environmental conservation of monetary values and the reasons for their selection. 3) Standard collection to strengthen environmental accounting. 4) Revision of the importance of environmental accounting policies. If changes are made to the importance of environmental accounting policies, status.

According to Proper is a Company Performance Rating Assessment Program in Environmental Management. This Proper is a continuous development program from PROKASIH (Clean River Program), which was developed in 2002. According to Soemohadiwijoyo (2017: 122), the 
Company Performance Rating Assessment program in Environmental Management (PROPER) indicators that state the level of environmental management performance of a company. The PROPER performance level was obtained from the assessment of the Ministry of Environment of the Republic of Indonesia. According to Soemohadiwijojo (2017: 122), the aim is to increase the role of companies in environmental management, as well as stimulants in meeting environmental regulations by companies. In essence, the purpose of this proper is for the company to comply with environmental regulations, and also the creation of the company's sense of awareness of the environment. According to Soemohadiwijoyo (2017: 123), based on the provisions of the environment ministry, there are five proper ratings 1)Black, 2) Red, 3) Blue, 4) Green, 5) Gold. Meanwhile, according to Nursasi (2017: 28), more complete valuation criteria can be seen in the Minister of Environment Regulation No. 5 of 2011 regarding proper rating performance rating programs divided into five colors with the understanding that stock prices are influenced by supply and demand law. The price of a stock is more likely to go up if a stock experiences excess demand and tends to go down if there is an offer. An increase in stock prices will bring profits for investors from a good stock performance capital gain is if the stock price increase is above or at least equal to the level of market index increase. Nursasi (2017: 29) Before talking about stock prices and stock performance, we should basically understand what understanding shares themselves are.

According to Fahmi (2014: 324), in the capital market, there are two types of shares that are most commonly known by the public, namely common stock (common stock) and special stock (preference stock). Where these two types of shares have their respective meanings and rules. Common stock is a securities sold by a company which explains the nominal value (rupiah, dollar, yen, etc.) where the holder is given the right to attend the GMS (general meeting of shareholders) and RUPBLS (general meeting of other shareholders ordinary) as well as the right to determine whether to buy a rights issue (limited share seller), which in turn at the end of the year will benefit in the form of dividends. Preferred stock of special stock are securities sold by a company that explains the nominal value (rupiah, dollar, yen, and so on) where the holder will get fixed income in the form of dividends that will be received every quarter (quarterly). This type of preferred stock includes preferred shares that can be converted to convertible preferred stock, callable preference shares with floating dividends, or adjustable-rate preferences.

As mentioned earlier, the rate of return (henceforth the term return is replaced with return) an investment is measured as the total profit or loss received by the investor (owner) during a certain period. Returns are often expressed in terms of changes in the value of assets (capital gain or capital loss) plus the amount of cash distribution that can be in the form of dividends or interest payments expressed as a percentage of the initial value of an investment period.

\section{METHODS}

The stages in this research flow include the preparation phase, the implementation phase, and the reporting stage. This research is a two-way research relationship between independent variables and dependent variables that are reciprocal, meaning that one variable can be a cause and also an effect on other variables, and vice versa. The purpose of this study is explanatory (explanatory research), where explanatory research is a type of research that explains the causal relationship between one variable with other variables through hypothesis testing. The object of this study is the Disclosure of environmental accounting for stock performance. Companies in use include manufacturing sector companies that have proper property from the Ministry of Environment and Forestry, which are listed on the Indonesia Stock Exchange in 2011-2015. The type of data used is a secondary data type.

The data taken is in the form of manufacturing companies listed on the Indonesia Stock Exchange and its code, and also takes in the form of an annual report record in which there is a stock return, and the second also takes an annual report note in which there is information about proper ranking 
notes from the Ministry of Environment and Forestry. Samples are all amounts with certain characteristics or characteristics that are in the population. And the sampling method used by researchers is Purposive Sampling.

Manufacturing sector companies listed on the Indonesia Stock Exchange, companies that publish annual reports continuously throughout the study period. The steps of data analysis techniques in this study are as follows: 1) Data collection from the Indonesia Stock Exchange. They are taking data on annual reports of companies in the manufacturing sector, in the annual report looking for proper property from the Ministry of Forestry Environment from 2011-2015 and taking data on annual reports on manufacturing sector companies, in the annual report looking for stock returns from 2011-2015. 2. Sorting out the manufacturing sector companies from 2011-2015, then make a proper rating table from 2011-2015. a) Sorting out stock returns for manufacturing sector companies from 2011 - 2015, Next, create a stock return data table from 2011-2015. b) After all the data is collected, then using simple linear regression analysis techniques, according to Subagyo (2010: 252), simple linear regression consists of two variables. One variable in the form of a dependent variable is given the symbol $\mathrm{Y}$ and the second variable in the form of an independent variable given the symbol $\mathrm{X}$ in practice researchers rarely conduct analysis or calculation and coefficient testing manually, here the researcher uses a statistical application program that is SPSS. The general form of the regression equation is expressed by a mathematical equation $\mathrm{Y}=\mathrm{a}+\mathrm{bx}+$ e. Where $\mathrm{Y}=$ Prediction value of the variable $\mathrm{Y}$ is based on the value of Variable $\mathrm{X}, \mathrm{a}=\mathrm{Y}$ intercept; is the value for $\mathrm{Y}$ when $\mathrm{X}=0, \mathrm{~b}=$ Slope or slope or average change in $\mathrm{y}$ for each change from one unit $X$, either increase or decrease. $X=$ Value of Variable $X$ selected $S$, e = error.

Hypothesis testing to determine whether accepted or rejected and interesting hypothesis. To get the hypothesis testing the influence of environmental accounting disclosure is measured using (proper) on stock returns then it is seen in the simple linear regression table, according to Sugiyono (356: 2015 ) if the t-test on environmental accounting disclosure variables is less than 0.05 then the environmental accounting disclosure hypothesis is on stock returns received or significant or vice versa.

\section{RESULTS AND DISCUSSION}

Disclosure of environmental accounting measured using proper ranking on stock performance measured using stock returns. It can be concluded that the data results that there is a significant influence between environmental accounting disclosures with stock returns. So this study produces the same results as previous research by Nurasi (2017 entitled the analysis of environmental accounting disclosures on financial performance, and stock performance of the results of this hypothesis research shows that there is a significant influence between environmental accounting disclosures on financial performance and stock performance. And also, Utami ( 2007) examined the titled empirical study of the relationship between environmental performance, financial performance, and market performance.

So it can be concluded that in a universal mannerrsal if the company gets a proper ranking, and the ranking is included and informed in the annual report, then the annual report will automatically be seen by the people who need it and this will affect the increase in share prices at the company, where the influence lies with the people who see and assess that this company has good value or good in managing environmental accounting disclosures. The more people who judge it well, the more opportunities people will have to make investments in companies that are good at managing their environment, from the events above, there will be a stage of rising share prices at the company. If the stock price starts to go higher, then the company can feel the positive impact that the company has done in its efforts to involve the company in complying with environmental accounting disclosures that are measured using proper ranking and also need to know, that if the Disclosure of environmental accounting can be used as an added value for companies that need in 
terms of accounting utility environment. The conclusion from this research is that if the proper ranking is revealed, it will affect stock returns. And that will get a good impact that if the Disclosure of environmental accounting can be used as an added value for companies that need in terms of the acquisition of environmental accounting. The conclusion from this research is that if the proper ranking is revealed, it will affect stock returns. And that will get a good impact that if the Disclosure of environmental accounting can be used as an added value for companies that need in terms of the acquisition of environmental accounting. The conclusion from this research is that if the proper ranking is revealed, it will affect stock returns. and that will get a good impact.

Proper is a company performance evaluation program in proper environmental management, which is a program from the Ministry of Environment and Forestry. If a company is registered to join this program, then the company will get a proper rating; there are five proper ratings (black, red, blue, green, and gold.) This means that a company that gets a proper black rating means that the company in overcoming its environmental accounting post is very poor. And if the company gets the value of gold, then the company is already very concerned about overcoming its post items. While return The stock concluded by the researcher is the level of controlling the results or the results obtained in conducting shares acquisition transactions that are short term.

\section{CONCLUSION}

This research used mining sector companies in 2011-2015, as many as 26 companies were sampled. Disclosure of environmental accounting is an independent variable (X) that is measured using an appropriate rating, while stock performance is a Dependent variable (Y). And based on the results of data analysis processed in the SPSS Version 16 application, it can be concluded as follows: If a company is registered to join this program, then the company will get the right rating, there are five appropriate ratings (black, red, blue, green, and gold.) Which means a company that gets a black rating means that the company in dealing with postal accounting environmental post is very bad. And if the company gets the value of gold, then the company is already very worried about overcoming its posts.

\section{REFERENCE}

Almilia, L. S., Wijayanto, D. (2007). Pengaruh Environmental Performance dan Environmental Disclosure terhadap Economic Performance. Depok: Proceedings The 1st Accounting Conference 7-9 November 2007.

Atmaja, L. S. (2008). Teori dan Praktik Manajemen Keuangan. Yogyakarta: CV Andi Offset.

Baridwan, Z. (2000). Intermediate Accounting. Edisi Ketujuh, Cetakan Pertama. BPFEE, Yogyakarta.

Belkaoui, A. R. (2006). Teori Akuntansi. Buku 1. Edisi kelima. Salemba Empat. Jakarta.

Carslaw, C. A. P. N., and Kaplan, S. E. (1991). An Examination of Audit Delay: Further Evidence from New Zealand. Accounting and Business Research, 22(85). 21-32.

Ghozali, I. (2009). Analisis Multivariate Dengan Program SPSS. Edisi IV. Semarang. Badan Penerbit Universitas Diponegoro.

Haholongan, R. (2016). Kinerja lingkungan dan kinerja ekonomi perusahaan manufaktur go public. Jurnal ekonomi dan bisnis. Volume XIX No. 3 desember 2016.

Hartono, J. (2009). Teori Portofolio dan Analisis Investasi. Edisi Keenam. Yogyakarta: BPFEYogyakarta.

Ikatan Akuntansi Indonesia. (2015). Standar Akuntansi Indonesia. Buku Satu. Salemba 4.

Jensen dan Meckling. (1976). The Agency Theory Of The Firm : Managerial Behavior, Agency Cost And Ownership Structure. Journal of Financial Economics 3 : 305-360. Diakses pada Tanggal 22 Oktober 2016. 
Nursasi, E. (2017). Analisis pengungkapan akuntansi lingkungan terhadap kinerja keuangan dan saham studi kasus pada sektor pertambangan. Jurnal dinamika dotcom .Vol 8 No.1 januari 2017.

Scott, W. R. (2000). Financial Accounting Theory, 2 edition, Prentice-Hall CanadaInc., Scarborough, Ontario.

Utami, W. (2007) Kajian Empiris Hubungan Kinerja Lingkungan, Kinerja Keuangan dan Kinerja Pasar: Model Persamaan Struktural. Makalah yang disajikan pada The 1st Accounting Conference, Faculty of Economics Universitas Indonesia, Depok

Utami, R. (2008). Pengaruh Pengungkapan Lingkungan Terhadap Kinerja Keuangan Dan Kinerja Saham. (Studi pada Sektor Perusahaan Pengusahaan hutan dan Pertambangan Umum). Skripsi.

Diakses

pada http://repository.uinjkt.ac.id/dspace/bitstream/123456789/8586/1/Rizky\%20Putri\%20Utami -FEIS 